\title{
The Power of Multinational Companies in a Global World The Focus of Corporate Governance and its Impact on Business Ethics
}

\author{
JOSÉ G. VARGAS-HERNANDEZ \\ University Center for Economic and Managerial Sciences, University of Guadalajara \\ Email: jvargas2006@gmail.com \\ MARIELA SANDOVAL-VALENCIA \\ University Center for Economic and Managerial Sciences, University of Guadalajara \\ JOSÉ SATSUMI LÓPEZ-MORALES \\ $\mathrm{PhD}$. Student, Universidad Cristóbal Colon, Veracruz, México. \\ Email : jsatsumi@gmail.com
}

\begin{abstract}
The aim of this work is to identify the conditions of globalization that have led to suppose that transnational corporations are economic agents that negatively impact on business ethics from the perspective of corporate governance. The method of study was based on a thorough theoretical and literature review and the results obtained confirm the negative impact, since the use of corporate social responsibility programs are strategies to increase profits and global power rather than to achieve social impact.
\end{abstract}

Key Words: Transnational firms, business ethics, globalization, corporate governance, corporate social responsibility.

\section{Introduction}

History has been a determining factor in the evolution of economic systems between nations as it is from this science, like all the nations in the world can turn to patterns that project and define their interests in the future. In such an event, it is important that developing economies over the years have been changing, as the markets in which they have been involved in a dynamic act, which involves a process of adaptation and integration by of each of the actors that contribute to these developments. These actors have been diverse and their intervention within the economic system has been remarkable, the degree of influence on economic policies, creating a diffusion of authority and the power centers of society.

At the beginning, the main actor was the nation-state. However, as a result of capitalism and globalization phenomena, actors from the private sector such as transnational corporations have had a significant intervention. This was done mainly by the conditions that the current economic system has given them to increase their power, such as the opening of trade markets, cross-border investment flows, changing financial schemes, development asymmetries between nations and the evolution of communications networks. So now the presence and mastery of various companies of this size have led to a significant impact on global society.

Therefore, the present study aims to identify the conditions of globalization which now have taken the TNCs to be considered power actors in the international system, in order to understand how this behavior has affected the business ethics and the welfare of society through corporate governance approach. 
Content is integrated as follows: In the first instance there is an account of the background that gave rise to the phenomenon of globalization from the economic point of view, in order to understand how transnational corporations have been key players in the private sector that have entered the political sphere derived from their influence and power over various nations in the world. Secondly, this paper shapes the problem to be studied, which seeks to find the social affectations that power of transnational corporations has developed as a result of their global power, it makes a justification using statistics and data on the presence of these companies in the global context in the last 20 years. Later, it is described these phenomena from the perspective of Global Governance regulation, starting from the external environment, using ethics as the key variable to understand the relationship of transnational corporations to society of the host country.

Finally, the results confirm the proposed course, since the impact of transnational corporations to society is negative, when it can be inferred that the nature of the owners along with the agents is to obtain greater wealth, so make use of ethics and social programs opportunistically to achieve that end. Consolidating its presence in the global environment and generating dependency for receiving states that have been unable to overcome the strategic actions and social impact developed by transnational corporations.

\section{Background of the problem}

Historically it was the breakdown of the bipolar East-West balance that happened after the fall of the Berlin Wall, which set the tone of the "New World Order" and thus, the dominance of the capitalist system, ushered in a period of great turmoil, since once toppled the communist system, the United States in 1944 through the Treaty of Bretton Woods presented to the other including European nations affected an image of a nation committed to ending authoritarianism and economic uncertainty around the world.

Initially it was presented the replacement of gold standard for a dollar standard and to regulate the change, it was created the International Monetary Fund (IMF), as well as World Bank (WB) to finance the war disasters and the General Agreement on Tariffs and Trade (GATT), leading to the proliferation of free trade areas (Aranda, 2008). Under the economic agreement described were the developed countries which became spear point to check the goodness of the capitalist system, a motive why lag countries were forced to join gradually, leading to the phenomenon of Economic Globalization

From the economic point of view, authors such as Friedman (1970), emphasize that globalization is a phenomenon characterized by technological innovation and its appearance in the world has been consolidated in stages. Although some scholars of the phenomenon cite the Industrial Revolution as the event that gave rise to this phenomenon, most state that consolidation occurred with a trade integration process dating from just about thirty years (Carbaugh, 2005).

It was the nineties when globalization accelerated through the privatization of public assets. Privatization is the action in which a state sells public property, putting it in the hands of the free market (Eun, 2007). While privatization can be seen from different perspectives, it is a clear example of how this phenomenon transcends borders, contracting the national control to the economic benefits provided by foreign corporations.

Therefore, the presence of the private sector via multinational companies did not wait, because the conditions of global markets represent great improvement opportunities, on the one hand is allowed to install their production complexes anywhere in the world, powering comparative advantages through the use of resources and production factors, same as in their countries of origin do not allow them to minimize costs to consolidate scale productions. Another form of globalization promoted by multinational companies is foreign direct investment, action that over the years has driven economic growth in underdeveloped economies through job creation and technology transfer. 
While it can be inferred that transnational corporations have been a private actor that has driven the economic growth of most nations in the world, also can be the development of global business. Not all companies in the world have the capacity, resources or adequate instruments for the system to act in their favor, in the detriment to the creation of competitive companies, that in large part because transnational corporations are seeking to meet one private gain leveraging market asymmetries and forgetting their social origin. Consequently, and due to the rapid changes that occurred after Globalization, from a critical perspective and specifically has been put into question the reliability and the positive impact of the system toward the behavior and ethics of multinational companies.

\section{Definition of the Problem}

The distinguishing feature of transnational corporations compared to multinational companies is that the former have subsidiaries in different parts of the world without keeping a parent or residence, as it is the case and happens with multinationals. For the purposes of this research it makes use only of transnational corporations or TNCs's for short, since by its nature and structure, they have to develop a freer behavior in the global market, to the extent that the combined sales of the top 200 corporations in the world are much larger than a quarter of world economic activity (Anderson, 2005).

Whereupon, these companies have developed a capacity to influence the decisions or policies that governments create for the regulation of society, limiting control of formal institutions in the absence of regulatory schemes and dependence that TNC's created to the host country for perceived economic benefits, even if in a particular way TNCs, like any other business, are seeking to maximize their individual benefit, in most cases, under the exploitation of the resources of the host country. Basically, its power basis consists on the control over scarce resources (Smith, 1974).

This leads to ask the question, as research problem: How the power of transnational corporations attributed by economic changes of globalization has managed to influence business ethics?

The importance of this research is to infer the social impact transferred by transnational corporations on business ethics and how it has been misrepresenting to the individualistic nature of the capitalist system itself and the phenomenon of globalization. With what it must be remembered the theoretical underpinnings of welfare economics, as described by Friedman in 1970 "... the responsibility of the executive is to manage the business according to its owners, who generally want as much money as possible, not to mention compliance of the basic rules of society established both in law and those embodied in ethical custom. "

\section{Justification}

The economic power of transnational corporations is undisputed. It is only necessary to point out some facts: In 2000, there was an average of 40000 transnational companies identified by the Global Policy Forum, which had more than 250000 international subsidiaries (Anderson, 2005), while for 2008 the United Nations Conference on Trade and Development noted the existence of an average of 79,000 TNCs with over 790,000 affiliates (UNCTAD, 2008), suggesting an increase of almost 50\% in just eight years, highlighting the involvement of oil companies, investment banking and manufacturing.

Speeches are common where it is mentioned how these companies have achieved higher economies than those achieved by some countries. For example, by 2000 it was estimated that of the 100 largest economies in the world, 51 are global corporations and only 49 are countries (Anderson, 2005). By 2009 their share rose to 44 companies in the top 100, however, their position in the ranking improved significantly, as the case of Wal-Mart who held the position 22, being the company with more economic influence even over nations like Sweden, Saudi Arabia and Venezuela (Malnight, 2010). 
Among the most important transnational companies are from different sectors and nationalities, mainly, American, Japanese, German and English, to name a few. Although one should think that the TNC's management is diverse in its origins, it results being unique that derives from global environment in which they developed. This condition has allowed them to reduce entry barriers and reach different corners in the world, using their power to achieve their maximum benefit without trying many times the social impact that this measure may cause.

It is important point out that TNC's from emerging economies has increased in recent years. According with Fortune Global 500 companies outside North Atlantic, Europe and Japan has risen from 26 in 1988 to 90 in 2009 (Goldstein \& Pusterla, 2010). It is outstanding evidence from importance that has taken the companies from emerging economies. In addition, the social work carried out by TNC's from emerging economies is an important issue.

That is, since the beginning it was hoped that the phenomenon of economic globalization would generate social cohesion through the elimination of borders that isolate ideologies and the possibility of having more resources, technological and operational capabilities to the rapid flow of information. However, the results have been discovered in the eyes of the world and that on the contrary, it has been remarkable the social segregation perceived at the macro level in the presence of strong asymmetries or market failure, so it is considered to TNC's as actors key for the emergence of such behavior.

For example, in the financial sector, banks boast of new global banking facilities, because the 31 largest banks in the world hold assets totaling $\$ 10.4$ billion and perceive particular sales of more than $\$ 800$ million. Without considering the difficulties that most of the world's population face in obtaining a small loan. About 4.8 billion to 5.6 million people in the world still live in countries where the average GDP per capita is less than one thousand dollars a year, and only few of these people have access to credit from transnational banks (Anderson, 2005).

\section{Theoretical Assumption}

The phenomenon of economic globalization has created a negative impact on society when transferring to TNCs a strong economic power. The assumption of this paper considers that catalyzing the mandated agents of the owners who control these corporations take business ethics as an opportunistic means to obtain higher individual profits.

The Behavior of Transnational Corporations in the Context of Globalization and its Impact on Society.

The reality in today's economies is that they no longer need to promote an efficient allocation of natural and human resources in a way that is beneficial to everyone in society. Rather, so far the economy has been driven by transnational corporations and the insatiable desire of their owners to make money and increase market position. TRNs are ignoring this desire to the concealment of job creation and growth of national income in recipient countries (Jobson, 2006).

So on the one hand there is a convergence trend. When the effects such as FDI, boost the host country's labor activity and in turn to segregation when resources are exploited or limit the competitiveness of local producers or the way that these companies develop strategies based on economies of scope (interaction between subsidiaries), leading to deficiencies in market structure. The development of global oligopolies generates dissemination of ethical principles in order to maximize their profits. Therefore, TNC's practices tend to converge to local corporate globalization model.

Therefore, in the table 1 below is a comparison of the effects caused by economic globalization, its impact on TNC's and their drive or detriment to society: 
Table 1. Effect of economic globalization, ETN's impact and social impact in the host country.

\begin{tabular}{|c|c|c|}
\hline $\begin{array}{c}\text { Effect of } \\
\text { Globalization }\end{array}$ & Impact for ETN's & $\begin{array}{l}\text { Social Impact in Host } \\
\text { Country }\end{array}$ \\
\hline $\begin{array}{c}\text { Opening of } \\
\text { commercial markets }\end{array}$ & $\begin{array}{l}\text { Developing strategies of intra industrial } \\
\text { trade (IIT, commercial interactions } \\
\text { between subsidiaries). } \\
\text { Trade regulations imposed by the WTO, } \\
\text { have limited the ability of governments of } \\
\text { less industrialized countries to modify the } \\
\text { behavior of TNC's which operate in their } \\
\text { territories. } \\
\text { Two-thirds of world trade is carried out by } \\
\text { transnational corporations and half of that } \\
\text { trade is done via IIT (Diaz, nod.). }\end{array}$ & $\begin{array}{l}\text { Intervention of oligopolistic } \\
\text { structures that limit } \\
\text { competition from small } \\
\text { producers. } \\
\text { Influence on local trade } \\
\text { policies. }\end{array}$ \\
\hline $\begin{array}{c}\text { Foreign direct } \\
\text { investment (FDI) }\end{array}$ & $\begin{array}{l}\text { Are a source of FDI and its main growth } \\
\text { has led major developing economies such } \\
\text { as China and India. } \\
\text { In } 2006 \text {, global FDI flows reached, } \\
\text { according to preliminary estimates, to } 1.23 \\
\text { billion, representing an increase of } 34 \% \\
\text { over the previous year ( } \\
\text { (CEPAL, 2006). }\end{array}$ & $\begin{array}{l}\text { Creation of jobs. } \\
\text { Economic spill over in the } \\
\text { host country. } \\
\text { Exploitation of natural } \\
\text { resources and exploitation of } \\
\text { cheap labor }\end{array}$ \\
\hline $\begin{array}{l}\text { Changes in financial } \\
\text { schemes }\end{array}$ & $\begin{array}{l}\text { Diversification of risks associated with } \\
\text { change domestic rates and interest rates. } \\
\text { Development of the carry trade and } \\
\text { arbitrage of change. } \\
\text { To decrease tax burden. }\end{array}$ & $\begin{array}{l}\text { Generation competitive } \\
\text { disadvantage with local } \\
\text { producers } \\
\text { Development of footloose } \\
\text { capital. }\end{array}$ \\
\hline $\begin{array}{l}\text { Evolution of } \\
\text { communications } \\
\text { network }\end{array}$ & $\begin{array}{l}\text { Fast and efficient access to different } \\
\text { regions in the world. } \\
\text { Improve interactions with customers }\end{array}$ & $\begin{array}{l}\text { Development conditional to } \\
\text { economic growth on the host } \\
\text { country. }\end{array}$ \\
\hline
\end{tabular}

\section{Source: Own elaboration}

As can be corroborated by the results of the table above, the globalization from the economic environment has been a complex phenomenon, the net result of many different forces, some other integrative and disintegrative, mainly in the area where TNC's operate.

\section{Who Regulates Transnational Corporations?}

As it was mentioned before, the ETN's have developed a major economic power, derived from the conditions created by globalization and the intervention of the development of economic policies of les developed nations for their very particular benefit, becoming actors with an impact on society. So the question in this issue would be who and what are the mechanisms to regulate them?.

The Organization for Economic Cooperation and Development (OECD), has proposed in 1999, The Principles of Corporate Governance. These precepts are based on agency theory proposed by Ross in 1973 . Most recently in 2011 OECD published Guidelines for Multinational Enterprises, it provide non-binding 
principles and standards for responsible business conduct in a global context consistent with applicable laws and internationally recognized standards (OECD, 2011)

Unlike suggesting neoclassical economics, in the sense that all agents involved in the market have complete information, i.e. know the state of technology, factor costs, quality of goods and market prices. It is appropriate to acknowledge that since markets are not perfect, largely profit-making depends on the ability to benefit from the information, which is generally incomplete and asymmetric information between agents, which leads to failure market. This can be defined Corporate Governance as the institutional, legal and economic context within which take place the distribution of control rights and cash flows to shareholders, managers and other stakeholders of the company (Eun CS, 2007).

That's why, that while corporate governance from a conventional perspective seeks to control, does not accurately reflect the conflicts of interest between owners, managers, workers and consumers. Thus, corporate governance must be interpreted in two areas: Internal through the problems that arise when the agent breaks the mandate of the owners or shareholders of generating greater economic benefits for the company for compliance with a particular interest, and the external environment as the impact of the organization on the global market trends, local politics or lobbyists (Denis, 2003).

The mechanisms that shareholders should use internally to control the agent are known as "monitoring costs" and may be referred to contracts or equity incentives. However, there is a gap in the external environment as a part of corporate governance has evaluated and created means of control for companies, especially large corporations, to address economic trends affecting its stability, while global level (emphasizing the nature of TNC's) have not defined the mechanisms to control these corporations to the social detriment generated.

Therefore, self-regulation is the key factor to understand the degree of power that currently economic units are reached through the reframing of their activities and the strategic use of the gaps created by the governments of the states in which have managed to. For example, one of the strategies employed by TNC's, has been the incorporation or establishment of nongovernmental organizations (NGO's) or cooperation with organizations of civil society, creating social interest groups who advocate common goals for the search of satisfaction of a social need, with the sole purpose of counteracting the caused damages.

Working with common goals to maintain order and human security of a nation, TNC's are reincorporating ethical principles that give rise to social welfare, taking advantage of the goal that the objective of any state political system is to support its causes to grow and consolidate, at the expense of incorporating various international links. That is, it must not forget that these tasks will continue to seek international links through trade and foreign investment to sustain their economic position. Only now these activities are framed by social causes such as the cultural and academic exchange strengthening internal cultural and educational institutions.

\section{The Ethical Implications for TNC's}

Based on the study of TNC's, a prominent element in its external environment are the interest groups, formed at the base by a hierarchical society of the host country who is harmed or benefited by the decisions made by the officials of those companies. With this, the ethics used turn effect, if agents fail to respect the rules and moral principles of the society in question. Therefore, it can be inferred that ethics is part of governance, because the morality of the agent, shareholders and board members can generate responsible practices with dual purpose, where on the one hand shareholders gain economic benefits and the process give back to the society through good deeds.

For compliance with ethical principles, the ETN's from the perspective of Corporate Governance has developed codes of ethics; principle created since the introduction of the Sarbanes-Oxley Act in 2002 to 
monitor U.S. companies listed on the stock and protect investors (Eun C. a., 2007). Since then the codes of ethics were identified as a separate written document, provisioned by the owners to a previous study of the environment, in order to be adopted on a voluntary basis and containing the ethical standards to guide the agent and the employee to correct behavior in national and international contexts (Schwartz, 2002).

Ideally, it could establish global codes of ethics, however, these codes do not stop being exclusive, putting as a condition for compliance regional characteristics, such as formal rules through legislation or even informal rules, culture or traditions. These codes are leaving transnational corporations the freedom to pursue particular strategies for the continuation of the company within the recipient country.

Once you understand the behavior of TNC's in the global environment, and the key concepts that define ethical practices, in order to understand the strategies according to the economic conditions of the system can incorporate TNC's, using their power and position to develop positive overall impact on society. In the next table it is presented the social practices based on ethical principles that have made the top 5 corporations around the world to improve their image and global presence. This list was taken from the International Monetary Fund in 2010 and his information was extracted from each of its web pages.

Table 2. Examples of transnational social work

\begin{tabular}{|c|c|c|}
\hline Transnational & Sector & Social work at global level \\
\hline WAL-MART STORES & Retail food sales & $\begin{array}{c}\text { Environmental sustainability } \\
\text { Hunger and nutrition } \\
\text { Women's Economic Empowerment } \\
\text { Veterans and military families } \\
\text { Diversity and inclusion } \\
\text { Ethical sources } \\
\end{array}$ \\
\hline ROYAL DUTCH SHELL & Oil & $\begin{array}{c}\text { Shell eco-maratón } \\
\text { Our neighbors } \\
\text { Social investment } \\
\text { Nigeria } \\
\text { HIV and AIDS } \\
\end{array}$ \\
\hline EXXON MOBIL & Oil & $\begin{array}{c}\text { Exxon Mobil Foundation } \\
\text { Malaria } \\
\text { Math and Science } \\
\text { Economic opportunities for women } \\
\text { Human rights } \\
\text { Corporate citizenship }\end{array}$ \\
\hline TOYOTA MOTOR & Automotive & $\begin{array}{c}\text { CSR initiatives } \\
\text { Environmental responsibility } \\
\text { Corporate citizenship } \\
\end{array}$ \\
\hline ING GROUP & Insurance & $\begin{array}{ll}\text { Sustainability policy } \\
\text { Social responsibility } \\
\end{array}$ \\
\hline TENARIS & Siderurgy & $\begin{array}{l}\text { Roberto Rocca Education Program } \\
\text { Social Assistance in catastrophes } \\
\text { Cultural Exchange in diferents locations } \\
\text { sponsor sports and leisure activities for our employees } \\
\text { and the local community. }\end{array}$ \\
\hline CEMEX & Cement & $\begin{array}{l}\text { Use of alternative fuels, such as chipped tires, household } \\
\text { waste and biomass such as animal meal. } \\
\text { Use of renewable energy to generate power for our } \\
\text { operations. } \\
\text { Support educational institutions. }\end{array}$ \\
\hline EMBRAER & Aerospace & $\begin{array}{l}\text { Safety at the work and occupational work. } \\
\text { Environment management practices. }\end{array}$ \\
\hline
\end{tabular}

Source: Own elaboration 
In addition, not only TNC's from developed countries have carried out social work. TNC's from emerging economies have carried out social work too. Three of the main corporations from Latin America are presented in Table 2. The importance of this region in the international business arena has been increasing in the last 20 years (Cuervo- Cazurra, 2010). Some TNC's from Latin America are important players in some industries, i.e Tenaris in siderurgy, CEMEX in cement and Embraer in aerospace industry.

\section{Social Responsibility and Corporate Citizenship. Social Contribution or Economic Expansion Strategies?}

From the actions received in the above table can highlight social responsibility practices and the addition of corporate citizenship. Both have proved positive strategies for expansion and dominance of many companies with global features. On the one hand, social responsibility in most of the definitions is assumed as normative plus regarding legal obligations. That is, it claims to be following scrupulously the legal framework, so that social responsibility would be essentially a series of voluntary agreements that the company is committed to meet and generates added value for this (Hernández, 2008).

Regarding corporate citizenship is a term created by Klaus Schwab, founder of the World Economic Forum, in order for companies to generate organizational social support to regions with lower incomes. However, the term was coined by TNC's, with basic economic purposes, as a society poor or low income, is a society that does not consume. Therefore the contributions that TNC's have done for social purposes take implicit in the generation of new consumers.

Therefore, currently many researchers in the field have struggled to define such concepts as a part both emanate from the intention to bring an action for the benefit of a social group in a vulnerable, yet its end as has already been demonstrated, goes beyond compliance, as companies driving the social programs have been used as strategic mechanisms to achieve better strategic and economic position as the ideal way to reduce the tax burden before performing a specific task proper of the state, making such actions in one trend of international marketing.

Thus social responsibility and corporate citizenship continues to be but a strategic leap forward in the model of economic relations between enterprises and society, with which, showing the "human face of global market" of which it spoke Kofi Annan, the TNC's has been able to convince everyone of the benefits of economic globalization (Ramiro, 2009).

\section{Analysis of Results}

It is easy to describe the solution to social conflicts generated by polarization gestated in the free market system with words like cooperation or integration, which are only for the correct key principles solution to the problems facing our world today. However, the difficulty to generate important changes for the benefit of a better society lies in the ability to achieve collective action and widespread interest. This resulted in large part by the lack of own collective values of ethical principles.

Globalization thus is no longer a phenomenon to channel integration, welfare and prestige that demand any state at global level, as it omits many principles based on that community. In turn, the tide seems brash and with great difficulty due to some problems such as: conflicts over resources like water and fossil fuels that generate a daunting environment every day, a progressive increase overcrowding, excessive growth of poverty, an international system that responds to individual interests of private entities gain greater power each day as it is the case of TNC's.

As it has been shown throughout the present work, the initial assumption raised is met, thus it can be said that the effects of the phenomenon of globalization have caused a negative impact on society by being 
immersed in activities that TNC's develop daily for the sake of their benefit. Thus, it can be inferred three key results:

A. The power of TNC's, stems from its false defense for the free market system, spare parts, and that this defense is essentially constituted by social programs that aim to create a mask solid to improve their public image. However, its real face is constituted by economic strategies that generate global structures benevolent to daily particular activity allowing extend their influence over governments and international institutions, including through reducing their tax burdens.

B. The ETN's, influence usually in handling international policies to promote their activities profitoriented from international organizations and within emerging economies whose economic conditions in most cases is less than that of such entities generating actions that hurt the country's society receptors, such as:

1) Explotation of natural resources.

2) Capital pintails (short-term investments that exploit resources of a host country and then move to another country).

3) Economy scope based strategies (intra-industry trade between subsidiaries).

4) Gestation of oligopolistic market structures.

C. The behavior, self-regulation and greed-driven practices of agents has repeatedly shown concern in their benefit and not the betterment of society, as stipulated in the corporate governance model based on the agency theory. Therefore, the laws and agreements created for its regulation are still intended for the exclusive use of the well-being of those entities.

\section{Conclusions and Recommendations}

Despite the TNC's appetite for profit regardless of the cost, it must be recognized that the ETN's are instruments that are used for the good of society. Since they have access to a variety of resources and technologies that improve the standard of living of millions of people, and better structured and more efficient than bureaucracy to handle certain social issues such as oil spills, natural disasters and distribution of food and medicines for the poor or people in vulnerable state.

The problem, however, is self-regulation of the activities of TNC's, its size that limits local competition, the development of scale economies favored by the exponential accumulation of wealth, the ability to move and their infiltration into the political arena that have allowed to evade any substantial regulations. Moreover it is important research if the kind of property (state and private) influence in the power of TNC's, tha state TNC's maybe take more advantage that the private TNC's.

Therefore, it should be noted the shortcomings of corporate governance on the control to TNC's and manage some recommendations:

A. No action mechanisms have been developed to balance the struggle for power, wealth and knowledge. This means that it has not been implemented strategies for competitive promotion that regulate the growth and concentration of oligopolistic market structure, as a priority state to provide the guidelines to follow for economic development. Although some strategies have increased the level of income of some nations, also generates conflicts with social decline, led by inequality, exploitation of the environment and poverty.

B. The regulation strategies should follow four fundamental principles for corporate governance, comprised of responsibility, accountability, fairness and transparency. Responsibility for TNC's to bring the exercise to obey the rules without coercion, equity and accountability that go along the 
increased transparency that should be applicable not only to the public organization, but also to private companies derived from their influences and social impact and finally equity as a means of fostering competition. However, the TNC's behavior remains away from these principles

Therefore it is clear that in the absence of control mechanisms on the international stage, a new economic system is emerging as the dispersion of power and authority of the states have fostered the growth of transnational private entities in spite of their ultimate goals, engage in social and political movements, not only on a regional scale but globally. This is derived from the lack of action by public institutional means, achieving the empowerment of a network of activists that certainly can wrest control of conflicts arising at the state level.

\section{References}

Anderson, S. a. (18 de February de 2005). The rise of global corporate power. Obtenido de United Nation website: http://globalpolicy.igc.org/socecon/tncs/top200.htm

Aranda, J. L. (15 de Noviembre de 2008). ¿Qué fue Bretton Woods? El país.

Carbaugh, R. J. (2005). La globalización de la actividad económica. En R. J. Carbaugh, Economía Internacional (págs. 4-8). Thomson.

CEPAL. (2006). Inversión extranjera directa y empresas .

Cuervo- Cazurra, A. (2010). Multilatinas. Universia Business Review. 14- 33

Denis, D. a. (2003). International Corporate Governance. Journal of financial and quantitative analysis.

Díaz, G. V. (s.f.). Globalización y comercio. Obtenido de Eumed: http://www.eumed.net/librosgratis/2008b/389/GLOBALIZACION\%20Y\%20COMERCIO.htm

Eun, C. a. (2007). La globalización y la empresa multinacional. En C. a. Eun, Administración Financiera Internacional (págs. 10-16). Mac GrawHill.

Eun, C. S. (2007). Gobierno Corporativo en el Mundo. En C. S. Eun, Administración Financiera Internacional (págs. 78-99). Mc GrawHill.

Friedman, M. (1970). The Social Responsability of Business Is to Increase Profits. The New York Times Magazine.

Goldstein, A. \& Pusterla, F. (2010). Emerging Economies Multinationals. International Journal of Emerging Markets, 5, 3/4, 289-306.

Hernández, Z. J. (2008). La Responsabilidad Social Corporativa . Centro de Documentación HEGOA.

Jobson, I. (2006). The Unseen World of Transnational Corporations' Powers. The Neumann Business Review, 23-30.

Malnight, T. K. (2010). Corporate Clout: The Influence of the World's Largest 100. Global trends.

OECD. (2011). Guidelines for Multinational Enterprise.

Ramiro, P. y. (2009). Análisis de la Responsabilidad Social Corporativa de las empresas Transnacionales Colombianas. Observatorio de Multinacionales en América .

Schwartz, M. (2002). A Code of Ethics for Corporate code of Ethics. Journal of Business Ethics, 27-43.

Smith, R.E. (1974). Private Power and National Sovereignity: some comments on the Multinational Corporation. Journal of Economics Issues. 2, 2, 417 a 447.

UNCTAD. (2008). World Investment Report: Transnational corporations and the infra estructure challenge. New York and Genova: United Nations. 